\title{
An Introduction to PROJECTIVE GEOMETRY
}

By L. N. G. Filon, C.B.E., M.A., D.Sc., F.R.S., Professor of Applied Mathematics in the University of London. New (Fourth) Edition, revised and enlarged. xvi +407 pages, 80 diagrams.

16s. net

Professor Filon has almost completely rewritten and greatly enlarged his well-known textbook without changing its plan except that the discussion of Involution now precedes that of foci and focal properties of the conic. The examples have been increased in number from 406 to 893 . A prospectus is available outlining in detail the scope of the new edition.

\section{PROBABILITY AND RANDOM ERRORS}

By W. N. Bond, M.A., D.Sc., A.R.C.S. viii +181 pages. 10s. 6d. net

Particularly written for chemists and physicists, and including numerous worked examples based on data such as are obtained in the laboratory.

\section{Principles of DESCRIPTIVE GEOMETRY}

By E. L. Ince, M.A., D.Sc. viii +152 pages, 153 diagrams. 8s. 6d. net

"This treatise fills a gap in English mathematical literature, since, as Dr. Ince points out, English writers deal with the methods rather than the principles of the subject."-Times Educational Supplement.

Prospectuses from $4 \mathrm{I}$ \& 43 Maddox Street, W. I

Edward Arnold \& Co., London

The Matuematical Association, which was founded in 1871, as the Association for the Improvement of Geometrical Teaching, aims not only at the promotion of its original object, but at bringing within its purview all branches of elementary mathematics.

Its purpose is to form a strong combination of all persons who are interested in promoting good methods of teaching mathematics. The Association has already been largely successful in this direction. It has become a recognised authority in its own department, and is continuing to exert an important influence on methods of examination.

“The Mathematical Gazette" (published by Messrs. G. Beil \& Sons, LTD.) is the organ of the Association. It is issued at least five times a year. The price per copy (to non-members) is usually 3s. each.

The Gazette contains-Articles, Notes, Reviews, etc., dealing with elementary mathematics, and with mathematical topics of general interest. 


\section{G. BELL \& SONS}

\section{ELEMENTARY TREATISE ON PURE MATHEMATICS}

By N. R. C. DOCKERAY, M.A. 16s. net

A Professor of Mathematics writes: "It is a book I welcome very much. There is nothing on the same lines in English, and its method will provide a far better preparation for a study of mathematics at the University stage than that given by the books at present in use."

"Teachers should welcome such an admirable textbook as this, for it is undoubtedly a real contribution to school mathematics."-NATURE.

"A well-designed and helpful textbook."-Journal of ED UCATION.

\section{MISCELLANEOUS EXERCISES IN SCHOOL MATHEMATICS}

Compiled by H. E. PIGGOTT, м.A., and D. F. FERGUSON, M.A.

Fifth edition. 45. 6d. Also in two parts, 2s. 6d. each.

The exercises number I400, and are grouped in four stages, Part I containing Stages A and B, the standard of Stage B being about that of the School Certificate. Stages C and D between them cover the ground of the Additional Mathematics for the School and Higher Certificates.

"A very valuable collection."-THE A.M.A.

"Well-selected . excellently produced is to be warmly commended."-SECONDARY EDUCATION.

YORK HOUSE, PORTUGAL STREET. W.G. 2 